\title{
Fruits of Scirpus (Cyperaceae) from the early Miocene of Weichang, Hebei Province, North China and their palaeoecological and palaeobiogeographical implications
}

\author{
Ping Lu' ${ }^{1}$, Ya Li $i^{2}$, Jian-Wei Zhang ${ }^{3}$, Xiao-Qing Liang ${ }^{1 *}$, Yue-Zhuo Li $i^{4}$ and Cheng-Sen Li ${ }^{5}$
}

\begin{abstract}
This paper describes the fossil fruits of Scirpus weichangensis X.Q. Liang, sp. nov. from the early Miocene of Guangyongfa Village, Weichang County, Hebei Province, North China. The fossil fruits are obovate in shape and their lateral sections are plumply trigonous. The cell walls of the surface are straight. The persistent stout bristles have downward-directed barbellae in distal 1/2. The occurrence of the fossil Scirpus indicates that Guangfayong was a wetland in the early Miocene. Based on the fossil data, the genus likely originated in Western Siberia in the Oligocene, spread during the Miocene, and was finally distributed worldwide in the Holocene.
\end{abstract}

Keywords: Scirpus, Early Miocene, Palaeoecology, Palaeobiogeography, Weichang

\section{Introduction}

Cyperaceae Juss. is a cosmopolitan family, with 106 genera and approximately 5400 species (Dai et al. 2010; Spalink et al. 2016). The family is in a range from sea level up to $5475 \mathrm{~m}$, covering large areas of swamp and arctic vegetation (Goetghebeur 1998). The family may have originated in the Late Cretaceous South America, and may have spread in the southern hemisphere via Antarctica (Spalink et al. 2016). Many fossils of Cyperaceae are mainly fruits or pollen. The biogeography of some genera of the family has been discussed based on fossil data, e.g. Cladium (Liang et al. 2017). Here, we report on the fruit fossils of Scirpus Linnaeus.

Scirpus Linnaeus (Cyperaceae) consists of herbs or perennials. The perianth has zero to six bristles. Nutlets with the beaked apexes are obovoid to ellipsoid and are biconvex to compressed 3-sided. They have smooth surfaces. Scirpus is distributed in North America, Mexico, Eurasia, Australia, and Pacific Islands (Whittemore and Schuyler 2002; Dai et al. 2010).

\footnotetext{
* Correspondence: liangxq@yxnu.edu.cn

'School of Chemistry, Biology, Environment, Yuxi Normal University, Yuxi 653100, Yunnan Province, China

Full list of author information is available at the end of the article
}

Fossil fruits of Scirpus have been collected in Europe, Asia, and North America. Scirpus foveolatus was found in the early Oligocene Siberia (Nikitin 2006). S. microcarpus Presl appeared in the Pliocene Canadian Arctic (Matthews and Ovenden 1990). S. atroviroides was collected in the Pliocene Czarnucha and the Pleistocene Łuków of eastern Poland (Stachowicz-Rybka 2005, 2015). Scirpus sp. occurred in the Holocene Rapa Nuiis, Polynesia (Horrocks et al. 2012).

Here we describe fossil fruits of Scirpus found from the early Miocene Weichang, North China; and further assign these fossil fruits to a new species, compare them with extant and fossil species, and discuss their biogeographical implications.

\section{Locality and stratigraphy}

The studied section is located in the Meiyaolin coal mine $\left(42^{\circ} 07^{\prime} 34^{\prime \prime} \mathrm{N}, 117^{\circ} 50^{\prime} 27^{\prime \prime} \mathrm{E}, 1396 \mathrm{~m}\right)$, near the Guangfayong Village of Weichang County, Hebei Province, North China (Fig. 1). The sediments mostly consist of mudstone, lignite, conglomerate, and shale. These sediments are similar to those developed in the Wuluogong section (Hannuoba Formation), and their geological age has been placed in the early Miocene 


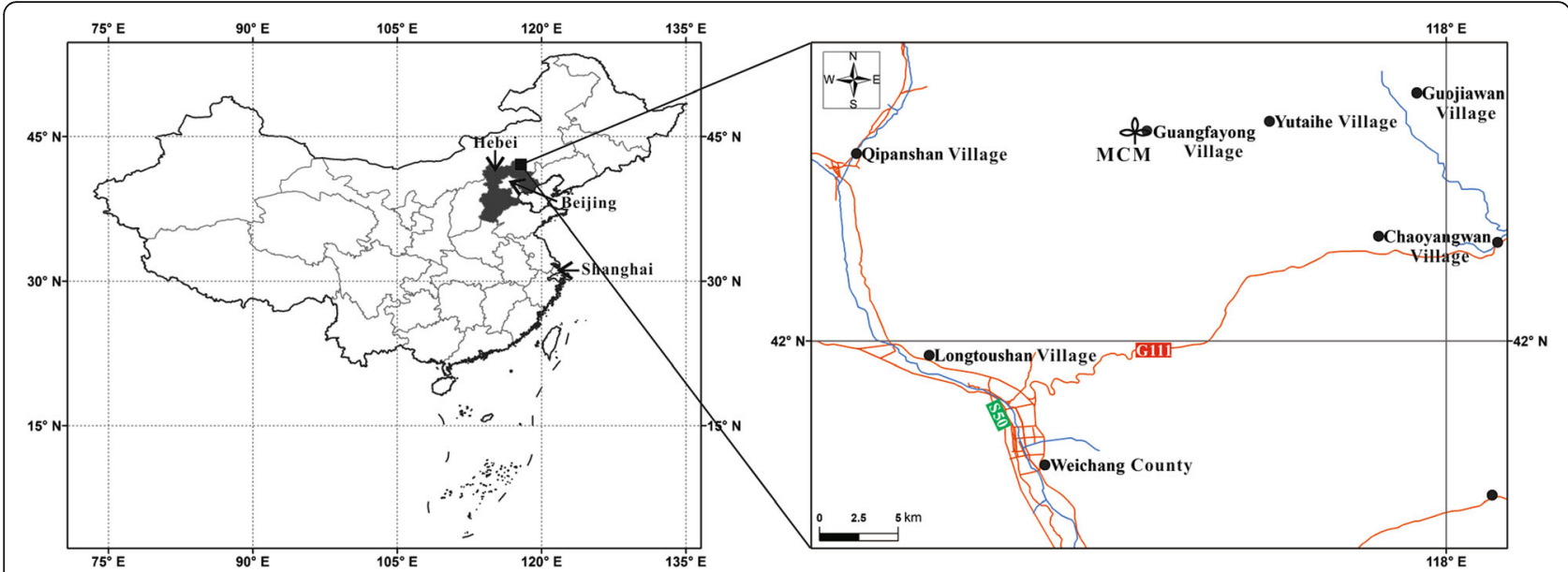

Fig. 1 Left shows the geographical location of the study area in North China; the map of China is modified after the GS (2016)2892 standard map from the State Bureau of Surveying and Mapping. Right shows the fossil site MCM (Meiyaolin coal mine) located at Guangfayong Village, Weichang County, Hebei Province, North China

(about 22.1 Ma) using the $\mathrm{K}-\mathrm{Ar}$ dating method (Li and Xiao 1980).

Many leaf and fruit fossils have been found in the Meiyaolin coal mine, including fossil examples such as Comptonia, Dusembaya, Lepidium, Medicago, Pinus, Ulmus, and Weigela (Liang 2009; Liang et al. 2010, 2013). Based on a palynological study, the early Miocene vegetation of Weichang can be characterized as a mixed temperate forest of conifers (e.g. Pinus, Picea, Tsuga) and broad-leaved trees (e.g. Betula, Alnus), with some subtropical plants (e.g. Carya). Its climate was warm temperate to subtropical (Li et al. 2009).

\section{Material and methods}

For this study, fossil fruits of Scirpus were collected from the $8^{\text {th }}$ layer of the section (see Li et al. 2009), which consists of mudstone and lignite. The fruits were isolated from the sediment using a procedure described by Wellman and Axe (1999), and were observed and scanned with a light microscope and scanning electron microscope (SEM) (ZEISS/EVO LS10). The terminology used is based on Berggren (1969).

\section{Systematics}

Family: Cyperaceae Juss.

Genus: Scirpus L.

Species: Scirpus weichangensis X.Q. Liang, sp. nov. (Plate 1).

Holotype: WCF-1-1 (Plate 1a).

Paratypes: WCF-1-2 (Plate 1b).

Type locality: Guangfayong Village, Weichang County, Hebei Province, North China.

Type formation and age: Hannuoba Formation, early Miocene.
Etymology: The specific name, weichangensis, is derived based on the fossil site in Weichang County.

Repository: National Museum of Plant History, Institute of Botany, Chinese Academy of Sciences, Beijing, China.

Diagnosis: Nut obovate. Lateral section slightly 3-sided. Persistent bristles 3 with downward-directed barbellae in the upper part. The style-base is point-like. Surface glabrous; epidermal cells distinct.

Description: Fossil fruits of Scirpus are obovate in outline, with a length of $0.88 \pm 0.04 \mathrm{~mm}$ and width of $0.65 \pm 0.05 \mathrm{~mm}$ (Plate 1). Their bases are cuneate (Plate 1a-d), and apexes are obtuse or apiculus (Plate $1 \mathrm{~b}, \mathrm{f}$ ). Their lateral sections are plumply trigonous (Plate 1a-d). The cell walls of the surface are straight (Plate 1). Three broken persistent bristles in the base are stout and have downward-directed barbellae in distal 1/2 (Plate 1a, d). The longest one is $0.73 \mathrm{~mm}$ in length and is as long as 0.85 times the length of the fruit (Plate 1a).

\section{Discussion}

5.1 Comparison of Scirpus weichangensis X.Q. Liang, sp. nov. with extant and fossil species

The fossil fruits from the early Miocene of Weichang are obovate with a slightly 3 -sided lateral section (Fig. 2). They have three stout persistent bristles with downward-directed barbellae (Fig. 2). They share similar characteristics with Cyperaceae with respect to the fruit outline, the lateral section, and bristles. As such, they belong to the family, with more than ninety genera. Among the genera, fruits of Scirpus L., Phylloscirpus C.B. Clarke, and Pseudoschoenus (C.B. Clarke) Oteng-Yeb. have persistent stout bristles with downward-directed barbellae. However, the fruits of Phylloscirpus have six bristles, and the cell walls of their 

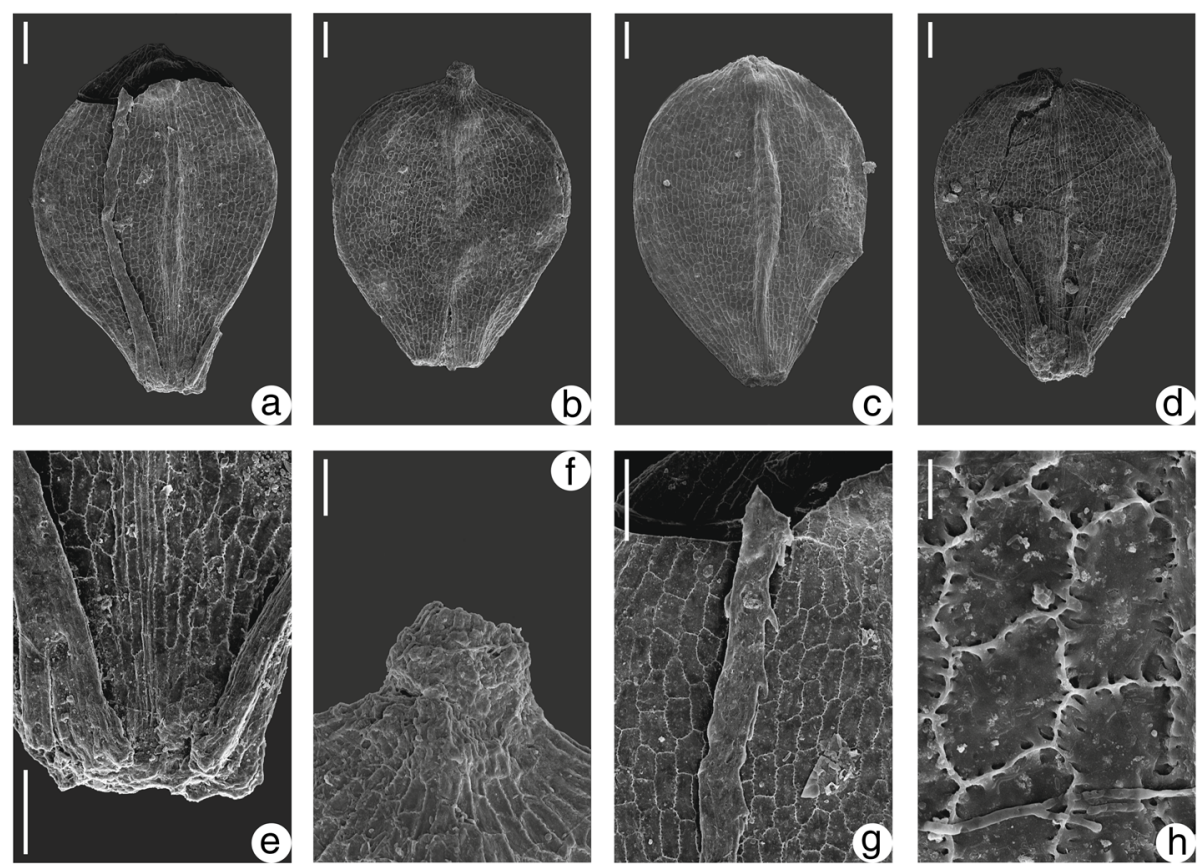

Plate 1 The fossil fruits of Scirpus weichangensis X.Q. Liang, sp. nov. from the early Miocene of Weichang, Hebei Province, North China. a-d - Fruits (WCF-1-1, WCF-1-2, WCF-1-3, WCF-1-4); e - Base of $\mathbf{a}$; $\mathbf{f}$ - Apex of $\mathbf{b} ; \mathbf{g}$ - Bristle of $\mathbf{a} ; \mathbf{h}$ - Surface of fruit of c. Scale bars: $\mathbf{a}-\mathbf{d}=100 \mu \mathrm{m} ; \mathbf{e}-\mathbf{g}=60 \mu \mathrm{m}$; $\mathrm{f}=30 \mu \mathrm{m} ; \mathrm{h}=9 \mu \mathrm{m}$

surfaces are minutely reticulate-foveolate. Pseudoschoenus have fruits with 3-5 (6) bristles (Goetghebeur 1998). Fruits of Schoenoplectus (Reichenbach) Palla have the faintly to prominently rugose or with transverse wavy ridges, and are $2.5-3.5 \mathrm{~mm}$ in length (Whittemore and Schuyler 2002). Fruits of Bolboschoenus (Ascherson) Palla are $2.3-5.5 \mathrm{~mm}$ long (Whittemore and Schuyler 2002). Nutlet surface of Schoenoplectiella Lye is smooth or transversely rugulose to sharply ridged, and epidermal cells are narrowly oblong to linear (Hayasaka 2012). Consequently, fossil fruits are ascribed as being part of Scirpus.

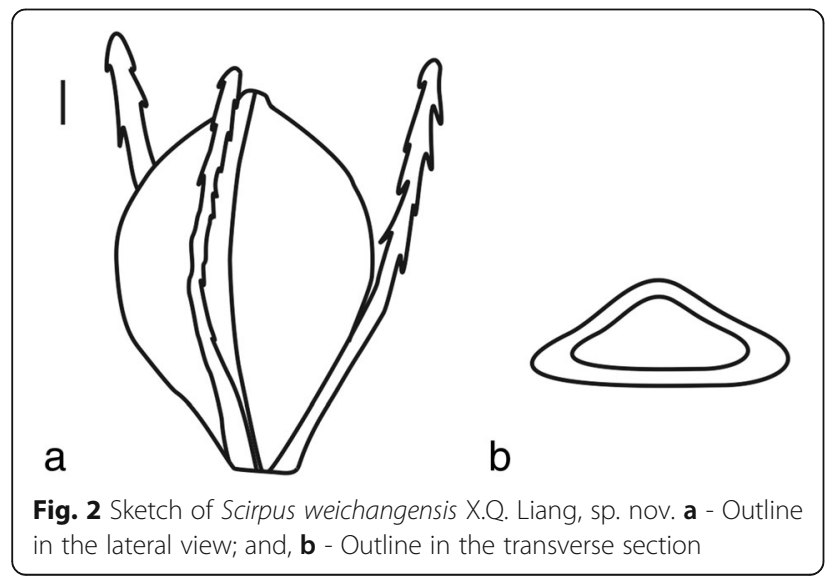

Within the genus, nineteen species have fruits with four, five or up to six bristles (e.g. S. orientalis, S. radicans, S. polyphyllus) (Oh and Ham 1998; Whittemore and Schuyler 2002; Dai et al. 2010) (Table 1). Fruits of $S$. atrocinctus Fernald, S. congdonii Britton, S. diffuses Schuyler, S. flaccidifolius (Fernald) Schuyler, S. lineatus Michaux, and S. longii Fernald have six slender bristles (Whittemore and Schuyler 2002). The fruits of S. polyphyllus Muell. and S. wichureae Boechkeler have filiform and silk-like bristles, respectively (Healy and Edgar 1980; Oh and Ham 1998; Wilson 1994; Dai et al. 2010) (Table 1).

Fruits of S. microcarpus Presl \& Presl have bristles with barbellae arranged almost to the base (Whittemore and Schuyler 2002) (Table 1). The bristles of S. georgianus Harper are much shorter than the fruit ( $\mathrm{Yu}$ 2003) (Table 1). The fruit barbellae of S. chunianus Tang \& Wang are near the apex of the bristles (Dai et al. 2010) (Table 1). Fruits of the S. rosthornii Diels are elliptic to subspherical in outline, and are smaller than the fossil fruits (Dai et al. 2010) (Table 1). The fruits of S. ternatanus Reinwardt ex Miquel are biconvex (Dai et al. 2010) (Table 1).

Many fossil fruits of Scirpus are obovate, e.g. S. foveolatus Nikitin from the early Oligocene Tyumen, S. clavatus Nikitin from the Oligocene Novosibirsk, $S$. chandlerae Nikitin from the late Oligocene, S. nagorskyi Dorofeev from the Miocene Tomsk, S. atroviroides Wieliczk from the Pliocene Czamucha and Pleistocene 
Table 1 Comparison of Scirpus weichangensis X.Q. Liang, sp. nov. with extant species

\begin{tabular}{|c|c|c|c|c|c|c|c|c|}
\hline Species & Shape & 3-sided & Length $(\mathrm{mm})$ & Width (mm) & Surface & Bristle & Barbellae $(\mu)$ & Reference \\
\hline$\overline{\text { Fossil }}$ & Obovate & + & $0.88 \pm 0.04$ & $0.65 \pm 0.05$ & Net & 3 & Apical half & This study \\
\hline S. orientalis Ohwi & $\begin{array}{l}\text { Obovate } \\
\text { to elliptic }\end{array}$ & Compressed & & & & $5-6$ & + & $\begin{array}{l}\text { Oh and Ham 1998; } \\
\text { Dai et al. } 2010\end{array}$ \\
\hline S. radicans Schkuhr & Obovate & Compressed & 0.9 & 0.5 & & 6 & Near apex & $\begin{array}{l}\text { Oh and Ham 1998; } \\
\text { Pignotti and } \\
\text { Mariotti 2004; } \\
\text { Dai et al. } 2010\end{array}$ \\
\hline $\begin{array}{l}\text { S. karuisawensis } \\
\text { Makino }\end{array}$ & $\begin{array}{l}\text { Oblong } \\
\text { to obovate }\end{array}$ & Compressed & 1 & & & 6 & Near apex & $\begin{array}{l}\text { Oh and Ham 1998; } \\
\text { Pignotti and } \\
\text { Mariotti 2004; } \\
\text { Dai et al. } 2010\end{array}$ \\
\hline S. lushanensis Ohwi & Elliptic & Compressed & 1.5 & 0.5 & & 6 & Near apex & Dai et al. 2010 \\
\hline S. wichurae Boeckeler & $\begin{array}{l}\text { Elliptic to } \\
\text { obovate }\end{array}$ & + & 1.3 & & & 6 (silk-like) & Apical half & $\begin{array}{l}\text { Oh and Ham 1998; } \\
\text { Pignotti and } \\
\text { Mariotti 2004; } \\
\text { Dai et al. } 2010\end{array}$ \\
\hline $\begin{array}{l}\text { S. ternatanus } \\
\text { Reinwardt } \\
\text { ex Miquel }\end{array}$ & $\begin{array}{l}\text { Elliptic, obovate, } \\
\text { subspherical }\end{array}$ & Biconvex & $0.7-1$ & & & $2-3$ & Apical half & $\begin{array}{l}\text { Pignotti and } \\
\text { Mariotti 2004; } \\
\text { Dai et al. } 2010\end{array}$ \\
\hline $\begin{array}{l}\text { S. chunianus } \\
\text { Tang \& Wang }\end{array}$ & $\begin{array}{l}\text { Elliptic to } \\
\text { subspherical }\end{array}$ & Biconvex & 1.5 & & Verruculose & $2-3$ & Near apex & Dai et al. 2010 \\
\hline S. rosthornii Diels & $\begin{array}{l}\text { Elliptic to } \\
\text { subspherical }\end{array}$ & Biconvex & $0.6-0.7$ & & & $2-3$ & Apical half & Dai et al. 2010 \\
\hline S. filipes Clarke & Obovate & Compressed & & & & 6 & + & Dai et al. 2010 \\
\hline S. hainanensis Huang & $\begin{array}{l}\text { Obovate to } \\
\text { broadly obovate }\end{array}$ & + & 1.5 & & & 6 & $\begin{array}{l}\text { Apically } \\
\text { pubescent }\end{array}$ & Dai et al. 2010 \\
\hline S. maximowiczii Clarke & $\begin{array}{l}\text { Narrowly } \\
\text { obovate }\end{array}$ & + & $1.8-2$ & 1 & & 6 & Near apex & Dai et al. 2010 \\
\hline $\begin{array}{l}\text { S. paniculatocorymbosus } \\
\text { Kükenthal }\end{array}$ & $\begin{array}{l}\text { Narrowly } \\
\text { obovate }\end{array}$ & + & 1.5 & & & 6 & & Dai et al. 2010 \\
\hline $\begin{array}{l}\text { S. ancistrochaetu } \\
\text { Schuyler }\end{array}$ & $\begin{array}{l}\text { Elliptic to } \\
\text { obovate }\end{array}$ & Plano-convex & $1.1-1.7$ & $0.6-0.8$ & & 6 & $\begin{array}{l}\text { In distal } \\
0.6-0.9\end{array}$ & $\begin{array}{l}\text { Whittemore and } \\
\text { Schuyler 2002; } \\
\text { Pignotti and } \\
\text { Mariotti } 2004\end{array}$ \\
\hline S. atrocinctus Fernald & $\begin{array}{l}\text { Elliptic or } \\
\text { obovate }\end{array}$ & $\begin{array}{l}\text { Plumply } \\
\text { trigonous or } \\
\text { plano-convex }\end{array}$ & $0.7-0.9$ & $0.4-0.5$ & & 6 (slender) & & $\begin{array}{l}\text { Whittemore and } \\
\text { Schuyler 2002; } \\
\text { Pignotti and } \\
\text { Mariotti } 2004\end{array}$ \\
\hline S. atrovirens Willdenow & $\begin{array}{l}\text { Elliptic or } \\
\text { obovate }\end{array}$ & $\begin{array}{l}\text { Plumply } \\
\text { trigonous or } \\
\text { plano-convex }\end{array}$ & (0.8-) 1.0-1.3 & $0.4-0.6$ & & $(5-) 6$ & $\begin{array}{l}\text { In distal } \\
0.3-0.6\end{array}$ & $\begin{array}{l}\text { Whittemore and } \\
\text { Schuyler 2002; } \\
\text { Pignotti and } \\
\text { Mariotti } 2004\end{array}$ \\
\hline S. congdonii Britton & $\begin{array}{l}\text { Obovate } \\
\text { or elliptic }\end{array}$ & $\begin{array}{l}\text { Plumply } \\
\text { trigonous or } \\
\text { plano-convex }\end{array}$ & $0.9-1.3$ & $0.6-0.8$ & & 6 (slender) & In distal 0.5 & $\begin{array}{l}\text { Whittemore and } \\
\text { Schuyler 2002; } \\
\text { Pignotti and } \\
\text { Mariotti } 2004\end{array}$ \\
\hline $\begin{array}{l}\text { S. cyperinus (Linnaeus) } \\
\text { Kunth }\end{array}$ & $\begin{array}{l}\text { Elliptic or } \\
\text { obovate }\end{array}$ & $\begin{array}{l}\text { Plumply } \\
\text { trigonous or } \\
\text { plano-convex }\end{array}$ & $0.6-0.9$ & $0.3-0.5$ & & 6 & & $\begin{array}{l}\text { Whittemore and } \\
\text { Schuyler 2002; } \\
\text { Pignotti and } \\
\text { Mariotti } 2004\end{array}$ \\
\hline S. diffuses Schuyler & $\begin{array}{l}\text { Obovate } \\
\text { or elliptic }\end{array}$ & Plano-convex & $0.9-1.3$ & $0.7-0.8$ & & 6 (slender) & In distal 0.5 & $\begin{array}{l}\text { Whittemore and } \\
\text { Schuyler } 2002\end{array}$ \\
\hline S. divaricatus Elliott & Elliptic-obovate & $\begin{array}{l}\text { Strongly trigonous } \\
\text { with very strong } \\
\text { angles and } \\
\text { concave sides }\end{array}$ & $0.8-1.0$ & $0.6-0.8$ & & 6 & In distal 0.5 & $\begin{array}{l}\text { Whittemore and } \\
\text { Schuyler 2002; } \\
\text { Pignotti and } \\
\text { Mariotti } 2004\end{array}$ \\
\hline S. expansus Fernald & $\begin{array}{l}\text { Oblong-elliptic } \\
\text { to broadly } \\
\text { elliptic or } \\
\text { obovate }\end{array}$ & $\begin{array}{l}\text { Plano-convex } \\
\text { or sometimes } \\
\text { plumply trigonous }\end{array}$ & $1.0-1.6$ & $\begin{array}{l}(0.6-) \\
0.8-1.0\end{array}$ & & 6 & $\begin{array}{l}\text { Almost } \\
\text { to base }\end{array}$ & $\begin{array}{l}\text { Whittemore and } \\
\text { Schuyler } 2002\end{array}$ \\
\hline
\end{tabular}


Table 1 Comparison of Scirpus weichangensis X.Q. Liang, sp. nov. with extant species (Continued)

\begin{tabular}{|c|c|c|c|c|c|c|c|c|}
\hline Species & Shape & 3-sided & Length $(\mathrm{mm})$ & Width $(\mathrm{mm})$ & Surface & Bristle & Barbellae $(\mu)$ & Reference \\
\hline $\begin{array}{l}\text { S. flaccidifolius } \\
\text { (Fernald) Schuyler }\end{array}$ & $\begin{array}{l}\text { Elliptic or } \\
\text { obovate }\end{array}$ & $\begin{array}{l}\text { Plano-convex or } \\
\text { plumply trigonous }\end{array}$ & $1.0-1.2$ & $0.4-0.6$ & & 6 (slender) & $\begin{array}{l}\text { In distal } \\
0.2-0.5\end{array}$ & $\begin{array}{l}\text { Whittemore and } \\
\text { Schuyler 2002; } \\
\text { Pignotti and } \\
\text { Mariotti } 2004\end{array}$ \\
\hline S. georgianus Harper & $\begin{array}{l}\text { Elliptic or } \\
\text { obovate }\end{array}$ & $\begin{array}{l}\text { Plumply trigonous } \\
\text { or plano-convex }\end{array}$ & $0.6-1.2$ & $0.4-0.5$ & & $0-3$ & & $\begin{array}{l}\text { Whittemore and } \\
\text { Schuyler 2002; } \\
\text { Pignotti and } \\
\text { Mariotti } 2004\end{array}$ \\
\hline S. hattorianus Makino & $\begin{array}{l}\text { Elliptic or } \\
\text { obovate }\end{array}$ & Plumply trigonous & (0.6-) 0.7-1.1 & $0.3-0.5$ & & (4-) 5-6 & $\begin{array}{l}\text { In distal } \\
(0.1-) \\
0.2-0.4\end{array}$ & $\begin{array}{l}\text { Whittemore and } \\
\text { Schuyler 2002; } \\
\text { Pignotti and } \\
\text { Mariotti } 2004\end{array}$ \\
\hline S. lineatus Michaux & Elliptic & $\begin{array}{l}\text { Plano-convex or } \\
\text { plumply trigonous }\end{array}$ & $0.1-1.5$ & $0.6-0.7$ & & 6 (slender) & & $\begin{array}{l}\text { Whittemore and } \\
\text { Schuyler 2002; } \\
\text { Pignotti and } \\
\text { Mariotti } 2004\end{array}$ \\
\hline S. longii Fernald & $\begin{array}{l}\text { Elliptic or } \\
\text { obovate }\end{array}$ & $\begin{array}{l}\text { Plano-convex or } \\
\text { plumply trigonous }\end{array}$ & $0.7-1.0$ & $0.4-0.5$ & & 6 (slender) & & $\begin{array}{l}\text { Whittemore and } \\
\text { Schuyler } 2002\end{array}$ \\
\hline $\begin{array}{l}\text { S. microcarpus Presl } \\
\text { \& Presl }\end{array}$ & $\begin{array}{l}\text { Ovate to } \\
\text { obovate }\end{array}$ & $\begin{array}{l}\text { Biconvex to } \\
\text { plano-convex }\end{array}$ & $0.7-1.6$ & $0.8-1.0$ & & $(3-) 4(-6)$ & $\begin{array}{l}\text { Arranged } \\
\text { almost } \\
\text { to base }\end{array}$ & $\begin{array}{l}\text { Whittemore and } \\
\text { Schuyler 2002; } \\
\text { Pignotti and } \\
\text { Mariotti } 2004\end{array}$ \\
\hline $\begin{array}{l}\text { S. pallidus (Britton) } \\
\text { Fernald }\end{array}$ & $\begin{array}{l}\text { Oblong-elliptic } \\
\text { to elliptic } \\
\text { or obovate }\end{array}$ & $\begin{array}{l}\text { Plumply trigonous } \\
\text { or plano-convex }\end{array}$ & $0.8-1.2$ & $0.4-0.6$ & & 6 & $\begin{array}{l}\text { In distal } \\
0.3-0.5\end{array}$ & $\begin{array}{l}\text { Whittemore and } \\
\text { Schuyler 2002; } \\
\text { Pignotti and } \\
\text { Mariotti } 2004\end{array}$ \\
\hline S. pedicellatus Fernald & $\begin{array}{l}\text { Elliptic or } \\
\text { obovate }\end{array}$ & $\begin{array}{l}\text { Plumply trigonous } \\
\text { or plano-convex }\end{array}$ & $0.7-0.9$ & $0.4-0.5$ & & 6 & & $\begin{array}{l}\text { Whittemore and } \\
\text { Schuyler } 2002\end{array}$ \\
\hline S. pendulus Muhlenberg & Elliptic & $\begin{array}{l}\text { Plano-convex or } \\
\text { plumply trigonous }\end{array}$ & $1.0-1.2$ & $0.6-0.8$ & & 6 & & $\begin{array}{l}\text { Whittemore and } \\
\text { Schuyler 2002; } \\
\text { Pignotti and } \\
\text { Mariotti } 2004\end{array}$ \\
\hline S. polyphyllus Vahl & $\begin{array}{l}\text { Obovate or } \\
\text { nearly obtriangular }\end{array}$ & $\begin{array}{l}\text { Plumply trigonous } \\
\text { or plano-convex }\end{array}$ & $1.1-1.4(-1.8)$ & $0.8-1.0$ & & 6 & In distal 1/2 & $\begin{array}{l}\text { Whittemore and } \\
\text { Schuyler 2002; } \\
\text { Pignotti and } \\
\text { Mariotti } 2004\end{array}$ \\
\hline S. polystachyus Muell. & $\begin{array}{l}\text { Ellipsoid } \\
\text { to obovoid }\end{array}$ & $\begin{array}{l}\text { Plano-convex or } \\
\text { with a distinct } \\
\text { dorsal angle }\end{array}$ & $1.2-1.5$ & $0.6-0.8$ & & $\begin{array}{l}\text { Many, } \\
\text { filiform }\end{array}$ & & $\begin{array}{l}\text { Healy and } \\
\text { Edgar 1980; } \\
\text { Wilson 1994 }\end{array}$ \\
\hline
\end{tabular}

Kathmandu (Dorofeev 1963; Stachowicz-Rybka 2005; Nikitin 2006; Bhandari et al. 2009). Moreover, fossil fruits of these species are commonly larger than fossil fruits from Weichang, e.g. S. foveolatus Nikitin from the early Oligocene Tyumen, S. clavatus Nikitin from the Oligocene Novosibirsk, and S. nagorskyi Dorofeev from the Miocene Tosmk (Dorofeev 1963; Nikitin 2006) (Table 2). Fruits of $S$. novorossicus Doweld from the late Miocene Odessa, Ukraine are ovate but also larger (Doweld 2018). S. nagorskyi Dorofeev from the Miocene Tomsk and S. atroviroides Wieliczk from the Pliocene Czamucha have fruits without bristles (Dorofeev 1963; Stachowicz-Rybka 2005). Scirpus sp. from the Pleitocene Kathmandu has fruits with the longitudinal epidermal cells and six to eight bristles (Bhandari et al. 2009).

No further more information about fossil fruits without bristles can be compared with materials from Weichang, e.g. S. microcarpus Presl from the Pliocene Ellesmere, and
Scirpus sp. from the Holocene Niederweningen (Switzerland), Rapa Nuiis (Polynesia), Connecticut (USA), Colorado (USA), and Jiangsu (China) (Pierce and Tiffney 1986; Matthews and Ovenden 1990; Drescher-Schneider et al. 2007; Li et al. 2008; Horrocks et al. 2012; Strickland et al. 2014). Thus, we ascribed fossil fruits from the early Miocene of Weichang to a new species, Scirpus weichangensis X.Q. Liang, sp. nov.

\subsection{Palaeoecological and palaeobiogeographical implication of Scirpus weichangensis}

Extant plants of Scirpus usually grow in wetlands, swamps, and marshes (Goetghebeur 1998). Scirpus weichangensis appeared in the early Miocene deposit in Weichang, with Weigela (Liang et al. 2013), indicating that Guangfayong was a wetland in the early Miocene, and then the wetland gradually disappeared as a result of land uplift. 
Table 2 Comparison of Scirpus weichangensis X.Q. Liang, sp. nov. with other fossil species

\begin{tabular}{|c|c|c|c|c|c|c|c|c|c|c|}
\hline Species & Shape & 3-sided & Length (mm) & Width (mm) & Surface & Bristle & Barbellae $(\mu)$ & Site & Epoch & Reference \\
\hline Fossil & Obovate & + & $0.88 \pm 0.04$ & $0.65 \pm 0.05$ & Net & 3 & Apical half & Weichang, China & Miocene & This study \\
\hline $\begin{array}{l}\text { S. foveolatus } \\
\text { Nikitin }\end{array}$ & Obovate & + & $2.5-3.4$ & $1.2-2.0$ & $\begin{array}{l}\text { Polygonal and } \\
\text { isodiametric }\end{array}$ & & & Tyumen & Oliocene & Nikitin 2006 \\
\hline $\begin{array}{l}\text { S. clavatus } \\
\text { Nikitin }\end{array}$ & & + & $1.6-2.1$ & $0.5-0.7$ & & & & Novosibirsk & Oliocene & Nikitin 2006 \\
\hline $\begin{array}{l}\text { S. chandlerae } \\
\text { Nikitin }\end{array}$ & $\begin{array}{l}\text { Ovate- } \\
\text { obovate }\end{array}$ & + & $1.2-1.6$ & $0.9-1.1$ & & & & Tomsk & Oliocene & Nikitin 2006 \\
\hline $\begin{array}{l}\text { S. nagorskyi } \\
\text { Dorofeev }\end{array}$ & & & $0.9-1.0$ & $0.3-0.5$ & & & & Tomsk & Miocene & Dorofeev 1963 \\
\hline $\begin{array}{l}\text { S. novorossicus } \\
\text { Doweld }\end{array}$ & Ovate & + & $1.4-2.1$ & $0.6-1.0$ & & & & Odessa, Ukraine & Miocene & Doweld 2018 \\
\hline $\begin{array}{l}\text { S. atroviroides } \\
\text { Wieliczk }\end{array}$ & Obovate & & 0.9 & 0.55 & Small-celled & & & Czarnucha & Pliocene & $\begin{array}{l}\text { Stachowicz-Rybka } \\
2005\end{array}$ \\
\hline Scirpus sp. & Obovate & & & & $\begin{array}{l}\text { Longitudinal } \\
\text { rows of cells }\end{array}$ & $6-8$ & & $\begin{array}{l}\text { Kathmandu, } \\
\text { Nepal }\end{array}$ & Pleistocene & $\begin{array}{l}\text { Bhandari et al. } \\
2009\end{array}$ \\
\hline
\end{tabular}

The fruit fossils of Scirpus were firstly found in the early Oligocene of Tyumen (Nikitin 2006). And, a noticeable point here is that we inclined to keep Nikitin's fossil species of Scirpus based on the fossil morphological information, although many fossil species of the genus have been ascribed to other genera (Doweld 2018). They appeared in the Miocene of Tomsk, Odessa and Weichang (Dorofeev 1963; Doweld 2018; and this study). They were collected in the Pliocene of Ellesmere Island, Echigawa, Prince Patrick Island, and Czarnucha (Matthews and Ovenden 1990;
Stachowicz-Rybka 2005; Yamakawa et al. 2008). They were found in the Pleistocene of Kathmandu, and Łuków (Bhandari et al. 2009; Stachowicz-Rybka 2015); and in the Holocene of Niederweningen, Rapa Nuiis, Hamden, Ziegler Reservoir, Sacramento-San Joaquin Delta, and Tangnan (James-West 1977; Pierce and Tiffney 1986; Drescher-Schneider et al. 2007; Li et al. 2008; Horrocks et al. 2012; Strickland et al. 2014).

Based on genus fossil data, Scirpus originated in the Oligocene of Siberia, and then migrated widely into

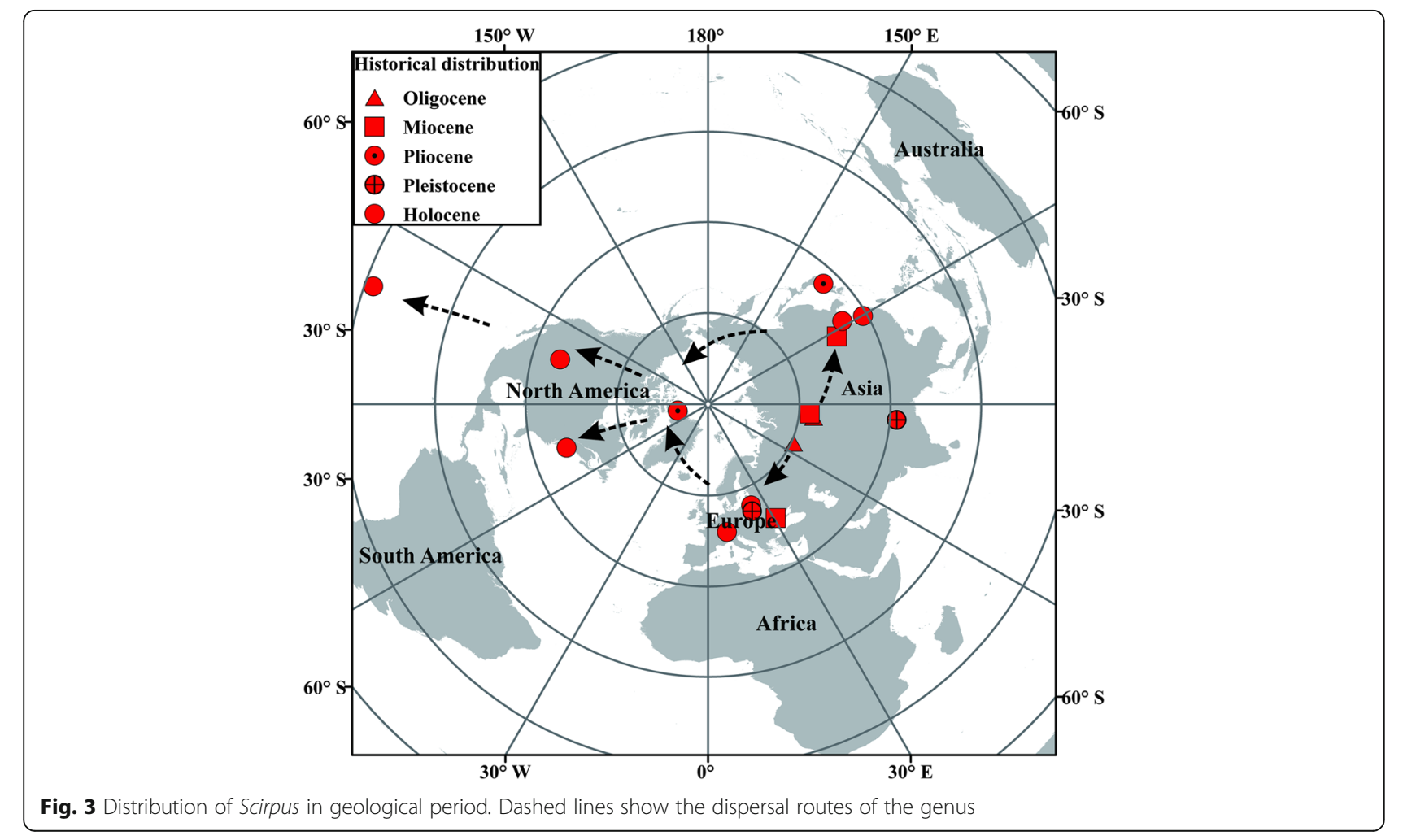


Europe and Eastern Asia during the Miocene. It occurred in North America through transoceanic dispersal in the Pliocene. Scirpus then spread widely around the world in the Holocene (Fig. 3).

\section{Conclusions}

Fossil fruits of Scirpus were first reported from Weichang County, Hebei Province, North China. They were obovate in the lateral view and trigonous in the transverse section, and had three stout persistent bristles with downward-directed barbellae in the apical half. Compared with extant and fossil species of the genus, they were ascribed to Scirpus weichangensis X.Q. Liang, sp. nov. Based on the systematic research of fossil fruits of Scirpus, this study could infer that its plants first occurred in the early Oligocene Siberia (S. foveolatus), and then appeared in the Miocene Asia (e.g. S. weichangensis), subsequently grew in North America in the Pliocene (e.g. S. microcarpus from Ellesmere Island, Canada) and in South Hemisphere in the Holocene (e.g. Scirpus sp. from Rapa Nuiis, Polynesia). And finally, distribution of the genus was nearly cosmopolitan.

\section{Acknowledgements}

The authors are grateful to the Central Lab of the Xishuangbanna Tropical Botanical Garden for their helps in SEM. Thanks are also expressed to two anonymous reviewers for their helpful comments.

\section{Funding}

This research was supported by grants from the National Natural Science Foundation of China (Nos. 31760057, 31860049, 41502017, 41072022).

\section{Availability of data and materials}

Information of data and material(s) was in figures, plate(s) and tables of the manuscript.

\section{Author contributions}

$\mathrm{X}$-QL and C-SL collected the materials. PL and X-QL carried out the experiment and wrote the manuscript. YL, J-WZZ, Y-ZL and C-SL helped modify the manuscript. All authors read and approved the final manuscript.

\section{Competing interests}

The authors declare that they have no competing interests.

\section{Publisher's note}

Springer Nature remains neutral with regard to jurisdictional claims in published maps and institutional affiliations.

\footnotetext{
Author details

${ }^{1}$ School of Chemistry, Biology, Environment, Yuxi Normal University, Yuxi 653100, Yunnan Province, China. ${ }^{2}$ CAS Key Laboratory of Economic Stratigraphy and Palaeogeography, Nanjing Institute of Geology and Palaeontology and Center for Excellence in Life and Paleoenvironment, Chinese Academy of Sciences, Nanjing 210008, Jiangsu Province, China. ${ }^{3}$ Xinjiang Institute of Ecology and Geography, Chinese Academy of Sciences, 818 South Beijing Road, Urumqi 830011, Xinjiang Uygur Autonomous Region, China. ${ }^{4}$ Qian-Dao-Hu Museum of Natural History, Hangzhou 311700 Zhejiang Province, China. ${ }^{5}$ State Key Laboratory of Systematic and Evolutionary Botany, Institute of Botany, Chinese Academy of Sciences, Beijing 100093, China.
}

Received: 18 September 2018 Accepted: 18 March 2019

Published online: 11 April 2019

\section{References}

Berggren, G. 1969. Atlas of seeds and small fruits of northwest European plant species with morphological descriptions. Part 2: Cyperaceae. Sweden: Berlingska Boktryckeriet.

Bhandari, S., A. Momohara, and K.N. Paudayal. 2009. Late Pleistocene plant macro-fossils from the Gokarna formation of the Kathmandu Valley, Central Nepal. Bulletin of the Department of Geology 12: 75-88.

Dai, L.-K., L. Song-Yun, L. Song-Jun, Z. Shu-Ren, T. Yan-Cheng, T. Koyama, G.C. Tucker, D.A. Simpson, H.J. Noltie, M.T. Strong, J.J. Bruhl, K.L. Wilson, and A.M. Muasya. 2010. Cyperaceae. In Flora of China, ed. Z.-Y. Wu, P.H. Raven, and D.Y. Hong, vol. 23. Beijing, Science Press: (Acoraceae through Cyperaceae).

Dorofeev, P.I. 1963. The Tertiary floras of Western Siberia. Leningrad: Izdatelstvo Akademii Nauk SSSR.

Doweld, A.B. 2018. New names of fossil Cyperaceae of northern Eurasia. Phytotaxa 356: 131-144.

Drescher-Schneider, R., C. Jacquat, and W. Schoch. 2007. Palaeobotanical investigations at the mammoth site of Niederweningen (Kanton Zürich), Switzerland. Quaternary International 164-165: 113-129.

Goetghebeur, P. 1998. Cyperaceae. In The families and genera of vascular plants IV flowering plants - Monocotyledons, ed. K. Kubitzki. Berlin: Springer.

Hayasaka, E. 2012. Delineation of Schoenoplectiella lye (Cyperaceae), a genus newly segregated from Schoenoplectus (Rchb.) Palla. Journal of Japanese Botany 87: 169-186.

Healy, A.J., and E. Edgar. 1980. Flora of New Zealand. Vol. III. Adventive cyperaceous, Petalous and Spathaceous monocotyledons. Wellington: Government Printer.

Horrocks, M., W.T. Baisden, J. Flenley, D. Feek, L.G. Nualart, S. Haoa-Cardinali, and T.E. Gorman. 2012. Fossil plant remains at Rano Raraku, Easter Island's statue quarry: Evidence for past elevated lake level and ancient Polynesian agriculture. Journal of Paleolimnology 48: 767-783.

James-West, G. 1977. Late Holocene vegetation history of the Sacramento-san Joaquin Delta. California: Cultural heritage section, California Departmentof Parks and Recreation.

Li, J., and Z.G. Xiao. 1980. Introduction of Qipanshan section (K-50-16), 1/200000 geological map of People's Republic of China. Beijing: Geological Map Printing Plant of China (in Chinese).

Li, J.-F., D.K. Ferguson, J. Yang, G.-P. Feng, A.G. Ablaev, Y.-F. Wang, and C.-S. Li. 2009. Early Miocene vegetation and climate in Weichang District, North China. Palaeogeography, Palaeoclimatology, Palaeoecology 280: 47-63.

Li, L., C. Zhu, L.-G. Lin, Q.-H. Zhao, G.-Y. Shi, and H.-B. Zhu. 2008. Transgression records between $7500-5400 \mathrm{BC}$ on the stratum of the Luotuodun site in Yixing, Jiangsu Province. Acta Geographica Sinica 63: 1189-1197.

Liang, X.-Q. 2009. The Early Miocene Flora of Weichang, Hebei, China. Ph.D. thesis, Institute of Botany. In Chinese Academy of Sciences. China: Beijing.

Liang, X.-Q., Y. Li, Z. Kvaček, V. Wilde, and C.-S. Li. 2013. Seeds of Weigela (Caprifoliaceae) from the Early Miocene of Weichang, China and the biogeographical history of the genus. Taxon 62: 1009-1018.

Liang, X.-Q., P. Lu, A. Tiwari, T. Su, and Z.-K. Zhou. 2017. New fossil record of Cladium (Cyperaceae) from the middle Miocene of Zhenyuan, SW China, and the palaeobiogeographical history of the genus. Review of Palaeobotany and Palynology 237: 1-9.

Liang, X.Q., V. Wilde, D.K. Ferguson, Z. Kvaček, A.G. Ablaev, Y.F. Wang, and C.S. Li. 2010. Comptonia naumannii (Myricaceae) from the early Miocene of Weichang, China, and the palaeobiogeographical implication of the genus. Review of Palaeobotany and Palynology 163: 52-63.

Matthews, J.V., and L.E. Ovenden. 1990. Late tertiary plant macrofossils from localities in Arctic/subarctic North America: A review of the data. Arctic 43: 364-392.

Nikitin, V.P. 2006. Paleocarpology and stratigraphy of the Paleogene and Neogene strata in Asian Russia. Novosibirsk: Academic publishing house.

Oh, Y.C., and E.J. Ham. 1998. A taxonomic study on Scirpus Linn. (Cyperaceae) of Korea. Korean Journal of Plant Taxonomy 28: 217-247.

Pierce, L.S., and B.H. Tiffney. 1986. Holocene fruit, seed and leaf flora from riverine sediments near New Haven, Connecticut. Rhodora 88: 229-252.

Pignotti, L, and L.M. Mariotti. 2004. Micromorphology of Scirpus (Cyperaceae) and related genera in South-West Europe. Botanical Journal of the Linnean Society 145: 45-58.

Spalink, D., B.T. Drew, M.C. Pace, J.G. Zaborsky, J.R. Starr, K.M. Cameron, T.J. Givnish, and K.J. Sytsma. 2016. Biogeography of the cosmopolitan sedges (Cyperaceae) and the area-richness correlation in plants. Journal of Biogeography 43: 1893-1904. 
Stachowicz-Rybka, R. 2005. Reconstruction of climate and environment in the Augustovian interglacial on the basis of select plant macrofossil taxa. Polish Geological Institute Special Papers 16: 127-132.

Stachowicz-Rybka, R. 2015. Record of environmental and climatic changes in middle Pleistocene sediments from Łuków (eastern Poland) on the basis of plant macroremains analysis. Acta Palaeobotanica 55: 68-93.

Strickland, L.E., R.G. Baker, R.S. Thompson, and D.M. Miller. 2014. Last interglacial plant macrofossils and climates from Ziegler reservoir, Snowmass Village, Colorado, USA. Quaternary Research 82: 553-566.

Wellman, C.H., and L. Axe. 1999. Extracting plant Mesofossils and Megafossils by bulk acid maceration. In Fossil plants and spores: modern techniques, ed. T.P. Jones and N.P. Rowe, 11-14. London: Geological Society of London.

Whittemore, A.T., and A.E. Schuyler. 2002. Scirpus Linnaeus. In: Committee, F.o.N.A E. (Ed.). Flora of North America Vol. 23: Magnoliophyta: Commelinidae (in part): Cyperaceae. New York: Oxford University Press, pp. 8-21.

Wilson, K.L. 1994. Cyperaceae. In Flora of Victoria Vol. 2, ferns and allied plants, conifers and monocotyledons, ed. N.G. Walsh and T.J. Entwisle. Melbourne: Inkata Press.

Yamakawa, C., A. Momohara, T. Nunotani, M. Matsumoto, and W. Yasuyuki. 2008 Paleovegetation reconstruction of fossil forests dominated by Metasequoia and Glyptostrobus from the late Pliocene Kobiwako group, Central Japan. Paleontological Research 12: 167-180.

Yu, Z.-C. 2003. Late Quaternary dynamics of tundra and forest vegetation in the southern Niagara escarpment, Canada. New Phytologist 157: 365-390.

\section{Submit your manuscript to a SpringerOpen ${ }^{\circ}$ journal and benefit from:}

- Convenient online submission

- Rigorous peer review

- Open access: articles freely available online

- High visibility within the field

- Retaining the copyright to your article

Submit your next manuscript at $\boldsymbol{\nabla}$ springeropen.com 